\title{
Article \\ Synthesis of a Poly(3-dodecylthiophene) Bearing Aniline Groups for the Covalent Functionalization of Carbon Nanotubes
}

\author{
Felipe Wasem Klein ${ }^{1,2}$, Jean-Philippe Lamps ${ }^{1}$, Matthieu Paillet ${ }^{2} \mathbb{D}$, Pierre Petit ${ }^{1, *}$ and Philippe J. Mésini ${ }^{1, * \mathbb{D}}$ \\ 1 Université de Strasbourg, CNRS, Institut Charles Sadron, 23 rue du Loess, F67000 Strasbourg, France; \\ felipe.wasem-klein@ics-cnrs.unistra.fr (F.W.K.); jean-philippe.lamps@ics-cnrs.unistra.fr (J.-P.L.) \\ 2 Laboratoire Charles Coulomb (L2C), Université de Montpellier, CNRS, F34095 Montpellier, France; \\ matthieu.paillet@umontpellier.fr \\ * Correspondence: petit@ics-cnrs.unistra.fr (P.P.); mesini@ics-cnrs.unistra.fr (P.J.M.)
}

check for updates

Citation: Wasem Klein, F.; Lamps, J.-P.; Paillet, M.; Petit, P.; Mésini, P.J. Synthesis of a Poly(3dodecylthiophene) Bearing Aniline Groups for the Covalent

Functionalization of Carbon

Nanotubes. Reactions 2021, 2, 473-485. https://doi.org/10.3390/ reactions 2040030

Academic Editors: Mariusz Mitoraj and Dmitry Yu. Murzin

Received: 28 September 2021 Accepted: 5 November 2021 Published: 11 November 2021

Publisher's Note: MDPI stays neutral with regard to jurisdictional claims in published maps and institutional affiliations.

Copyright: (c) 2021 by the authors. Licensee MDPI, Basel, Switzerland. This article is an open access article distributed under the terms and conditions of the Creative Commons Attribution (CC BY) license (https:/ / creativecommons.org/licenses/by/ $4.0 /)$.

\begin{abstract}
The functionalization of carbon nanotubes by polymers necessitates two steps, first their modification by oxidizing them or by covalently attaching small compounds to them, then the growth of the polymer chains from these anchors or their grafting onto them. In order to better control the process and the rate of functionalization, we develop polymers able to covalently react with the carbon nanotubes by their side chains in one step. We describe the synthesis of a copolymer of dodecylthiophene and its analogue bearing an aniline group at the end of the dodecyl side chain. This copolymer can functionalize single-walled carbon nanotubes (SWNTs) non-covalently and disperse more SWNTs than its hexyl analogues. UV-Vis and fluorescence spectroscopies show that in these non-covalent hybrids, the polymer forms p-stacked aggregates on the SWNTs. The noncovalent hybrids can be transformed into covalent ones by diazonium coupling. In these covalent hybrids the polymer is no longer p-stacked. According to Raman spectroscopy, the conformation of the poly(3-hexylthiophene) backbone is more ordered in the non-covalent hybrids than in the covalent ones.
\end{abstract}

Keywords: carbon nanotubes; alkylation; diazonium; polythiophene; photoluminescence; Raman spectroscopy

\section{Introduction}

Covalent functionalization of carbon nanotubes has proved to be efficient to endow them with new properties, such as enhanced solubility [1,2], compatibilization in polymer matrices [3-5], and photoluminescence [6,7]. One of the main procedures for covalent functionalization is the diazonium coupling reaction, which presents a high efficiency [8], a good control [7,9], and can be adapted to different environments [10]. Most notably, this reaction is capable of attaching aryl groups even to polymer-wrapped carbon nanotubes [11], overcoming the steric hindrance of the dispersing agent. In most functionalization methods, the nanotubes are first functionalized by oxidation or by reaction with small compounds such as aniline derivatives [12-14]. Then polymers are grown from those reactive anchors or grafted onto them. However, this synthetic scheme comprises two steps, which limits the control of the functionalization rate.

In order to overtake this problem, we propose a functionalization in one-step by attaching the functional group directly to the polymer chain. In our previous work, [15] we have synthesized PHTcoAHT, a statistical copolymer based on poly(3-hexylthiophene) and bearing aniline side groups. This copolymer forms non-covalent hybrids with singlewalled carbon nanotubes (SWNTs) and can also react with the SWNTs in one step to form covalent hybrids. The synthesis had been designed to yield the polymer with high regioregularity, notably with no detectable head-to-head arrays. This regioregularity favors 
planar conformation and has enabled us to study the conformation of main chains in both types of hybrids. These have very different structures: in the non-covalent hybrids the polymer forms aggregates of few extended planar chains interacting through $\pi-\pi$ interactions with SWNTs; in the covalent ones the polymer does not $\pi$-stack on the SWNTs and does not form aggregates on their walls, and as shown by Raman spectroscopy, the main chain is disordered like in regiorandom P3HT. These differences between both hybrids are attributed to the aniline appended chains which, in the covalently grafted ones, act as a spacer between the SWNTs and the PHTcoAHT backbone.

Moreover, with these functionalized polymers we have observed only a very low amount of functionalized SWNTs in the final suspensions. A possible reason for this limited yield is the relatively low capacity of P3HT to exfoliate SWNTs in THF. The length of the side chains may influence the formation and the structure of the hybrids. Indeed, it has been observed with other conjugated copolymers [16-18], that longer side-chains can disperse larger amounts of nanotubes. In this context, we describe the synthesis of a new polymer bearing aniline side groups, but with longer side chains: a copolymer of 3-dodecylthiophene and its aniline appended derivative. SWNTs were functionalized covalently and non-covalently with this copolymer. The resulting hybrids were studied by UV-Vis-NIR, fluorescence and Raman spectroscopies.

\section{Materials and Methods}

\subsection{General Methods}

NMR spectra were recorded on a WH-400 MHz spectrometer from Bruker (Wissembourg, France) and were reported in $\delta$ ppm relative to $\mathrm{Me}_{4} \mathrm{Si}$. The FTIR spectra were recorded on a Vertex 70 spectrometer (Bruker Optics, Karlsruhe, Germany) equipped with an ATR diamond reflection unit.

Size exclusion chromatography: analytical and preparative SEC were carried out according the previously described procedure [15].

UV-Vis-NIR spectra were recorded with a Cary 5000 (Varian, Palo Alto, CA, USA) or a Lambda 25 spectrometer (Perkin-Elmer, Villebon, France).

Fluorescence spectra were measured with a E348 fluorimeter from HORIBA-JobinYvon (Palaiseau, France). The suspensions characterized by UV-Vis (with rather high absorbance) have been analyzed with a triangular cell to avoid internal filter effects.

Raman spectra were recorded using an Acton SP2500 spectrometer fitted with a PyLoN CCD detector and a 1800 grooves per mm grating (Teledyne Princeton Instrument, Trenton, NJ, USA). The samples were excited at $633 \mathrm{~nm}(1.96 \mathrm{eV})$ using a He-Ne laser through a $50 \times$ objective (Numerical Aperture 0.5 ) and $0.1 \mathrm{~mW}$ impinging on the sample.

\subsection{Synthesis of the Monomers}

2-(12-bromododecyl)oxy)tetrahydro-2 $\mathbf{H}$-pyran (3): Amberlyst $15^{\circledR}$ resin (3 g) was suspended in a solution of 12-bromododecanol (5 g, $18.9 \mathrm{mmol})$ in $\mathrm{CH}_{2} \mathrm{Cl}_{2}(50 \mathrm{~mL})$ under Ar. 3,4-dihydro- $2 \mathrm{H}$-pyran $(1.74 \mathrm{~g}, 20.7 \mathrm{mmol})$ was added and the suspension was stirred $90 \mathrm{~min}$ at $20^{\circ} \mathrm{C}$. The resin was filtered and the medium evaporated under vacuum. The raw product was purified by chromatography $\left(\mathrm{SiO}_{2}\right.$, cyclohexane/AcOEt 96/4 v/v) to yield pure 3 as a colorless oil ( $4.91 \mathrm{~g}, 74 \%$ yield). ${ }^{1} \mathrm{H}$ NMR $\left(400 \mathrm{MHz}, \mathrm{CDCl}_{3}\right) \mathrm{d}(\mathrm{ppm}): 4.58$ $(\mathrm{dd}, J=4.6,2.7 \mathrm{~Hz}, 1 \mathrm{H}, \mathrm{OCHO}), 3.88(1 \mathrm{H}$, pyran CHHO), $3.74(\mathrm{dt}, J=9.6,6.8 \mathrm{~Hz}, 1 \mathrm{H}, \mathrm{CHH}-$ OTHP), $3.47\left(\mathrm{~m}, 1 \mathrm{H}\right.$, pyran CHHO), 3.40-3.34 (m, 3H, CHH-OTHP $\left.+\mathrm{CH}_{2} \mathrm{Br}\right), 1.89-1.33$ $\left(\mathrm{m}, 24 \mathrm{H}, \mathrm{CH}_{2}\right) .{ }^{13} \mathrm{C}$ NMR $\left(100 \mathrm{MHz}, \mathrm{CDCl}_{3}\right) \mathrm{d}(\mathrm{ppm}): 98.9(\mathrm{OCHO}), 67.8\left(\right.$ dodec. $\left.\mathrm{CH}_{2} \mathrm{O}\right)$, 62.3 (pyran $\mathrm{CH}_{2} \mathrm{O}$ ), $34.1\left(\mathrm{CH}_{2}-\mathrm{Br}\right.$ ), $32.9\left(\mathrm{CH}_{2} \mathrm{CH}_{2} \mathrm{Br}\right.$ ), 30.9 (pyran C3), 29.8,29.63, 29.61, 29.58, 29.55, 29.50, 28.8 (dodec.C9), 28.3 (dodec. C10), 26.3 (dodecyl C3), 25.7 (pyranC4), 19.8 (pyran C5). FTIR (solid, ATR diamond) $v\left(\mathrm{~cm}^{-1}\right): 2923\left(v_{\mathrm{as}} \mathrm{CH}_{2}\right), 2853\left(v_{\mathrm{s}} \mathrm{CH}_{2}\right), 1465$, 1453, 1440, 1352, 1260, 1200, 1162, 1134, 1120, 1077, 1032, 1021. HRMS $\left(E S I \mathrm{Na}^{+}\right): m / z$ : 371.1576 $\left(\mathrm{MNa}^{+}\right)$, calcd for $\mathrm{C}_{17} \mathrm{H}_{33} \mathrm{BrO}_{2}$ : 371.1556. Elem. Anal. C 58.40, H 9.58; calcd for $\mathrm{C}_{17} \mathrm{H}_{33} \mathrm{BrO}_{2}$ : C 58.45, $\mathrm{H} 9.52$. 
3-(12-(tetrahydro-2H-pyran-2-oxy)dodecyl)thiophene (4): A suspension of magnesium turnings ( $0.38 \mathrm{~g}, 15.7 \mathrm{mmol}, 1.1$ eq. $)$ in anhydrous THF $(25 \mathrm{~mL})$ was heated at $50{ }^{\circ} \mathrm{C}$ and a chip of iodine was added. Ten percent of the total amount of $3(5 \mathrm{~g}, 14.3 \mathrm{mmol})$ was introduced and heated $2 \mathrm{~h} 30$. When $\mathrm{Mg}$ started to react, the rest of 3 was added dropwise and the mixture heated until most of the $\mathrm{Mg}$ has been consumed. The organomagnesium solution was cooled at $20{ }^{\circ} \mathrm{C}$ and kept under Ar. In a separate flask, a solution of 3-bromothiophene (2.8 g, $17.2 \mathrm{mmol}, 1.1$ equiv.) and $\mathrm{Ni}(\mathrm{dppp}) \mathrm{Cl} 2$ (0.39 g, $715 \mu \mathrm{mol}$, 0.05 equiv.) in anhydrous THF $(25 \mathrm{~mL})$ were stirred at $25^{\circ} \mathrm{C}$ under Ar. The organomagnesium solution was added dropwise and the resulting mixture heated at reflux for $30 \mathrm{~h}$. The reaction was quenched with water and extracted with cyclohecxane/EtOAc $(1 / 1 v / v$, $3 \times 5 \mathrm{~mL})$. The combined organic layers were dried $(\mathrm{MgSO} 4)$ and concentrated under vacuum. The crude was purified by chromatography (SiO2, cyclohexane/EtOAc 96/4 v/v) to afford an oil containing $85 \%$ of the desired compound $4,7 \%$ of $\mathrm{C}_{12} \mathrm{H}_{25} \mathrm{OTHP}$ and $8 \%$ of $\mathrm{BrC}_{12} \mathrm{H}_{24} \mathrm{OTHP}$, that was used as is in next step (3.93 $\mathrm{g}, 69 \%$ yield, taking into account impurities). ${ }^{1} \mathrm{H} \mathrm{NMR}\left(400 \mathrm{MHz}, \mathrm{CDCl}_{3}\right)$ : d (ppm): $7.26(\mathrm{dd}, J=4.9,3.0 \mathrm{~Hz}, 1 \mathrm{H}$, thiophene $\mathrm{H} 5)$, 6.95-6.91 (m, 2H, thiophene $\mathrm{H} 2$ and H4), $4.58(\mathrm{dd}, J=4.4,2.7 \mathrm{~Hz}, 1 \mathrm{H}, \mathrm{OCHO}), 3.85(\mathrm{~m}$, $1 \mathrm{H}$, pyran CHHO), $3.72(\mathrm{dt}, J=9.6,6.8 \mathrm{~Hz}, 1 \mathrm{H}, \mathrm{CHH}-\mathrm{OTHP}), 3.48(\mathrm{~m}, 1 \mathrm{H}$, pyran CHHO), $3.37(\mathrm{dt}, J=9.6,6.6 \mathrm{~Hz}, 1 \mathrm{H}, \mathrm{CHH}-\mathrm{OTHP}), 2.65\left(\mathrm{t}, J=7.3 \mathrm{~Hz}, 2 \mathrm{H}\right.$, thiophene- $\left.\mathrm{CH}_{2}\right), 1.89-1.79$ (m, 1H, THP C3-HH), 1.78-1.48 (m, 18H, $\left.\mathrm{CH}_{2}\right), 1.45-1.30\left(\mathrm{~m}, 8 \mathrm{H}, \mathrm{CH}_{2}\right)$.

3-(12-bromododecyl)thiophene (5): A solution of unpurified 4 (100 mg, $284 \mu \mathrm{mol})$ and $\mathrm{CBr}_{4}\left(132 \mathrm{mg}, 397 \mu \mathrm{mol}, 1.4\right.$ equiv.) in anhydrous $\mathrm{CH}_{2} \mathrm{Cl}_{2}(5-10 \mathrm{~mL})$ is stirred at 0 ${ }^{\circ} \mathrm{C}$ under $\mathrm{Ar} . \mathrm{PPh}_{3}$ (208 mg, $793 \mu \mathrm{mol}, 2.8$ equiv.) was added, the mixture warmed to $25{ }^{\circ} \mathrm{C}$ and stirred for $12 \mathrm{~h}$. The mixture was filtered on Celite ${ }^{\circledR}$, poured in $\mathrm{Et}_{2} \mathrm{O}$, filtered again, and evaporated under vacuum. The crude was purified by chromatography $\left(\mathrm{SiO}_{2}\right.$, EtOAc/cyclohexane 2/98 v/v) to afford pure 5 as an oil (69 mg,73\% yield). ${ }^{1} \mathrm{H}$ NMR (400 $\left.\mathrm{MHz}, \mathrm{CDCl}_{3}\right) \mathrm{d}(\mathrm{ppm}): 7.24(\mathrm{dd}, J=4.9,3.0 \mathrm{~Hz}, 1 \mathrm{H}$, thiophene H5), $6.94(\mathrm{~m}, 2 \mathrm{H}$, thiophene $\mathrm{H} 2$ and $\mathrm{H} 4), 3.14\left(\mathrm{t}, J=6.9 \mathrm{~Hz}, 2 \mathrm{H}, \mathrm{CH}_{2} \mathrm{Br}\right), 2.64\left(\mathrm{t}, J=7.8 \mathrm{~Hz}, 2 \mathrm{H}\right.$, thiophene- $\left.\mathrm{CH}_{2}\right), 1.86$ (m, 2H, dodecyl $\left.\mathrm{CH}_{2} \mathrm{CH}_{2} \mathrm{Br}\right), 1.63$ (m, 2H, dodecyl C2-H2), 1.24 (C10-H2), 1.19-1.38 (m, 14H, dodecyl C3-C9- $\left.\mathrm{H}_{2}\right) .{ }^{13} \mathrm{C}$ NMR (100 MHz, $\left.\mathrm{CDCl}_{3}\right) \mathrm{d}(\mathrm{ppm}): 143.0$ (thiophene C3), 128.3 (thiophene C4), 125.3 (thiophene C5), 120.0 (thiophene C2), $34.2\left(\mathrm{CH}_{2} \mathrm{Br}\right), 33.0\left(\mathrm{CH}_{2} \mathrm{CH}_{2} \mathrm{Br}\right.$ ), 30.7 (dodecyl C3), 30.4 (dodecyl C2), 29.9 (dodecyl C9), 29.73, 29.71, 29.67, 29.61, 29.59, 29.5 (dodecyl C7) 28.9 (dodecyl C9), 28.3 (dodecyl C10). HRMS (ESI+): m/z: $331.1083\left(\mathrm{MH}^{+}\right.$); calcd for $\mathrm{C}_{16} \mathrm{H}_{27} \mathrm{BrS} 331.1090$. Elem. anal. C 58.05, $\mathrm{H} 8.28$; calcd for $\mathrm{C}_{16} \mathrm{H}_{27} \mathrm{BrS}$ : C 58.00; H 8.21.

2-Bromo-3-(12-bromododecyl)thiophene (6): A solution of 5 (174 mg, $513 \mu \mathrm{mol}$, 1 equiv.) and $\mathrm{AcOH}(1.5 \mathrm{~mL})$ in $\mathrm{CHCl} 3(5 \mathrm{~mL})$ was stirred at $0{ }^{\circ} \mathrm{C}$ under Ar. A solution of $\mathrm{N}$-bromosuccinimide $(91.3 \mathrm{mg}, 0.103 \mathrm{mmol}, 1$ equiv.) in $\mathrm{CHCl} 3(1.8 \mathrm{~mL})$ was added in fractions of $5 \mathrm{~mL}$ spaced by $15 \mathrm{~min}$. After disappearance of 5 (followed by TLC), the solution was neutralized with a $2 \mathrm{M} \mathrm{NaOH}$ solution, mixed with water $(10 \mathrm{~mL})$ and extracted with EtOAc $(3 \times 40 \mathrm{~mL})$. The organic phases were dried $(\mathrm{MgSO} 4)$ and concentrated under vacuum. The crude was purified by flash chromatography $\left(\mathrm{SiO}_{2}\right.$, cyclohexane) to afford pure 7 as a yellow oil (90 mg, 43\% yield). ${ }^{1} \mathrm{H} \mathrm{NMR}\left(400 \mathrm{MHz}, \mathrm{CDCl}_{3}\right) \mathrm{d}(\mathrm{ppm}): 7.20$ $(\mathrm{d}, J=5.6 \mathrm{~Hz}, 1 \mathrm{H}$, thiophene $\mathrm{H} 5), 6.80(\mathrm{~d}, J=5.6 \mathrm{~Hz}, 1 \mathrm{H}$, thiophene H4), $3.42(\mathrm{t}, J=6.9$ $\left.\mathrm{Hz}, 2 \mathrm{H}, \mathrm{CH}_{2} \mathrm{Br}\right), 2.57\left(\mathrm{t}, J=7.6 \mathrm{~Hz}, 2 \mathrm{H}\right.$, thiophene $\left.-\mathrm{CH}_{2}\right), 1.87(\mathrm{p}, 2 \mathrm{H}, J=7.0 \mathrm{~Hz}$, dodecyl C11-H2), 1.52-1.64 (m, 2H, hexyl C2-H $), 1.38-1.50\left(\mathrm{~m}, 2 \mathrm{H}\right.$, dodecyl C10- $\left.\mathrm{H}_{2}\right), 1.23-1.38(\mathrm{~m}$, 14H, dodecyl C3-C9-H $\left.\mathrm{H}_{2}\right){ }^{13} \mathrm{C} \mathrm{NMR}\left(100 \mathrm{MHz}, \mathrm{CDCl}_{3}\right) \delta$ (ppm): 142.1 (thiophene C3), 128.4 (thiophene C4), 125.3 (thiophene C2), 108.9 (thiophene C5), $34.2\left(\mathrm{CH}_{2} \mathrm{Br}\right), 33.0$ (dodecyl C11), 29.9 (dodecyl C1), 29.72, 29.67, 29.57, 29.54, 29.4 (dodecyl C7), 28.9 (dodecyl C9), 28.3 (dodecyl C10). HRMS (ESI+): $m / z$ : $455.9973\left(\mathrm{MH}^{+}\right.$); calcd for $\mathrm{C}_{16} \mathrm{H}_{26} \mathrm{Br}_{2} \mathrm{~S}$ 455.9978. Elem. anal. C 46.61, $\mathrm{H}$ 6.53; calc. for $\mathrm{C}_{16} \mathrm{H}_{26} \mathrm{Br}_{2} \mathrm{~S}$ : C 46.84, $\mathrm{H} 6.39$.

2-Bromo-3-(12-bromododecyl)-5-iodothiophene (2): A solution of 6 (200 mg, $483 \mu \mathrm{mol})$ and acetic acid $(1.5 \mathrm{~mL})$ in $\mathrm{CHCl}_{3}(5 \mathrm{~mL})$ was stirred at $0{ }^{\circ} \mathrm{C}$ under Ar. $N$-Iodosuccinimide (108 $\mathrm{mg}, 483 \mu \mathrm{mol}, 1$ equiv.) was added. When 7 was no longer detected by TLC, the mixture was mixed with aq. $\mathrm{NaOH}(3 \mathrm{M}, 25 \mathrm{~mL})$ and extracted with $\mathrm{CHCl}_{3}(2 \times 10 \mathrm{~mL})$. The 
organic phase was washed with aq. $\mathrm{Na}_{2} \mathrm{~S}_{2} \mathrm{O}_{3}$, dried $\left(\mathrm{MgSO}_{4}\right)$ and evaporated. The crude was chromatographed $\left(\mathrm{SiO}_{2}\right.$, cyclohexane) to yield pure 2 as a solid $(210 \mathrm{mg}, 81 \%$ yield). ${ }^{1} \mathrm{H}$ NMR $\left(\mathrm{CDCl}_{3}, 400 \mathrm{MHz}\right) \delta(\mathrm{ppm}): 6.97(\mathrm{~s}, 1 \mathrm{H}$, thiophene $\mathrm{H} 4), 3.41(\mathrm{t}, 2 \mathrm{H}, J=6.9 \mathrm{~Hz}$, $\left.\mathrm{CH}_{2} \mathrm{Br}\right), 2.53\left(\mathrm{p}, J=7.5,15.0 \mathrm{~Hz}, 2 \mathrm{H}\right.$, thiophene- $\left.\mathrm{CH}_{2}\right), 1.86\left(\mathrm{~m}, 2 \mathrm{H}\right.$, dodecyl $\left.\mathrm{C} 11-\mathrm{H}_{2}\right), 1.53$ $\left(\mathrm{p}, J=7.6 \mathrm{~Hz}, 2 \mathrm{H}\right.$, dodecyl C2- $\left.\mathrm{H}_{2}\right), 1.50-1.40\left(\mathrm{~m}, 2 \mathrm{H}\right.$, dodecyl C3- $\left.\mathrm{H}_{2}\right), 1.12-1.34(\mathrm{~m}, 14 \mathrm{H}$, dodecyl C4-C10- $\left.\mathrm{H}_{2}\right) .{ }^{13} \mathrm{C}$ NMR $\left(\mathrm{CDCl}_{3}, 100 \mathrm{MHz}\right) \delta(\mathrm{ppm}): 144.3$ (thiophene $\left.\mathrm{C} 3\right), 138.0$ (thiophene C4), 111.8 (thiophene $\mathrm{C} 2), 71.2$ (thiophene C5), $34.2\left(\mathrm{CH}_{2}-\mathrm{Br}\right), 32.9$ (dodecyl C11), 29.74, 29.68, 29.62, 29.61, 29.55, 29.46, 29.3, 29.2 (dodecyl C7), 28.9 (dodecyl C9), 28.3 (dodecyl C10). HRMS (ESI+): m/z: $533.9093\left(\mathrm{M}^{+}\right)$; calcd for $\mathrm{C}_{16} \mathrm{H}_{25} \mathrm{Br}_{2} \mathrm{IS}$ : 533.9007 .

\subsection{Synthesis of the Polymers}

The synthesis of copolymer PHTcoAHT was described previously [15].

Poly(3-dodecylthiophene-co-3-(12-bromododecyl)thiophene)(A). In a $200 \mathrm{~mL}$ reactor, $i-\mathrm{PrMgCl}\left(2 \mathrm{M}\right.$ in THF) was added slowly to THF $(120 \mathrm{~mL})$ at $0{ }^{\circ} \mathrm{C}$. The absorption of the solution was followed in situ by an UV-Vis probe. The addition was continued until the absorption of organomagnesium between 250 and $270 \mathrm{~nm}$ was persistent. 1 (397 mg, $86.9 \mu \mathrm{mol})$ and $2(84 \mathrm{mg}, 15.6 \mu \mathrm{mol})$ were added. $i-\operatorname{PrMgCl}(2 \mathrm{M}$ in THF) was added slowly to metallate not more than $90 \%$ of the monomer. Small volumes were taken from the medium and hydrolyzed with $\mathrm{CD}_{3} \mathrm{OD}$. The NMR spectra of these samples allowed to measure the rate of metallated monomers (singlet at $6.90 \mathrm{ppm}$, Figure 1). The mixture was heated to $20^{\circ} \mathrm{C}$ and $\mathrm{Ni}(\mathrm{dppp}) \mathrm{Cl}_{2}(3.78 \mathrm{mg}, 7.16 \mu \mathrm{mol}, 0.007$ equiv.) was added. The polymerization was followed by the increase of the absorption at $440 \mathrm{~nm}$. After it reached a plateau, the reaction was stopped with $100 \mu \mathrm{L}$ of aqueous $\mathrm{HCl}(2 \mathrm{M})$. The solution volume was reduced of $80 \%$ by evaporation and the polymer was precipitated in methanol $(10 \times$ the volume of the remaining solution). The precipitate was centrifuged (9500 rpm, $2 \mathrm{~h}$ ) and dried under vacuum for $24 \mathrm{~h}$ to yield copolymer A $(234 \mathrm{mg}, 83 \%)$. It was further purified by preparative GPC in $\mathrm{CHCl}_{3} .{ }^{1} \mathrm{H}$ NMR $(400 \mathrm{MHz}, \mathrm{CDCl}): \delta(\mathrm{ppm}) 6.99(\mathrm{~s}, 1 \mathrm{H}$, thiophene C4-H), $3.39\left(\mathrm{t}, 0.33 \mathrm{H}, J=6.8 \mathrm{~Hz}, \mathrm{CH}_{2} \mathrm{Br}\right), 2.75-2.90\left(\mathrm{~m}, 2 \mathrm{H}\right.$, thiophene- $\left.\mathrm{CH}_{2}\right), 1.84(\mathrm{p}, 0.33$ $\left.\mathrm{H}, J=6.9 \mathrm{~Hz}, \mathrm{CH}_{2} \mathrm{CH}_{2} \mathrm{Br}\right), 1.66-1.78\left(\mathrm{~m}\right.$, dodecyl C2- $\left.\mathrm{H}_{2}\right), 1.50-1.17\left(\mathrm{~m}, 18 \mathrm{H}, \mathrm{CH}_{2}\right), 0.88(\mathrm{~m}$, $\left.3 \mathrm{H}, \mathrm{CH}_{3}\right) .{ }^{13} \mathrm{C}$ NMR $\left(100 \mathrm{MHz}, \mathrm{CDCl}_{3}\right) \delta$ (ppm): 140.0 (thiophene $\mathrm{C} 3$ ), 133.9 (thiophene C4), 130.6 (thiophene $\mathrm{C} 2$ ), 128.8 (thiophene $\mathrm{C} 5), 34.1\left(\mathrm{CH}_{2} \mathrm{Br}\right), 33.0$ (bromododecyl C11), 32.1 (dodecyl C3), 30.7 (dodecyl C2), 29.9, 29.83, 29.76, 29.68; 29.54 (bromododecyl C9), 28.4 (bromododecyl C10), $22.8\left(\mathrm{CH}_{2} \mathrm{CH}_{3}\right), 14.3\left(\mathrm{CH}_{3}\right)$. FTIR (ATR diamond) $v\left(\mathrm{~cm}^{-1}\right): 3400$ (aromatic $v \mathrm{CH}), 2956\left(v_{\mathrm{as}} \mathrm{CH}_{3}\right), 2918\left(v_{\mathrm{as}} \mathrm{CH}_{2}\right), 2850\left(v_{\mathrm{s}} \mathrm{CH}_{2}\right), 1509$ (aromatic $\left.v \mathrm{CC}\right), 1466$, $1455,1377\left(\delta \mathrm{CH}_{3}\right), 1260,1086,1031 ; 818,802,719$.

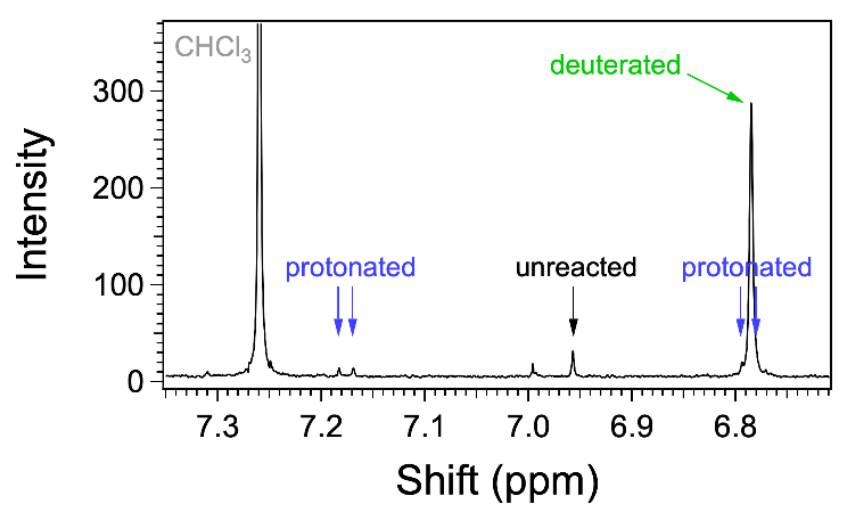

Figure 1. Measurement of the active monomer: an aliquot of the reaction medium was neutralized by $\mathrm{CD}_{3} \mathrm{OD}$. The active species is deuterated in position 5 and yields a singlet. The species yielding two doublets at 7.17 and $6.79 \mathrm{ppm}$ comes from the deactivation of the magnesium by protonated impurities in the medium.

Poly(3-dodecylthiophene-co-3-(12-(4-(diphenylimino)phenoxy)dodecyl)thiophene) (B): $\mathrm{K}_{2} \mathrm{CO}_{3}(80.1 \mathrm{mg}, 580 \mu \mathrm{mol}, 10$ equiv.), and 4-[(diphenylmethylene) amino]phenol 
(78.5 mg, $283 \mu \mathrm{mol}, 4.9$ equiv.), $\mathrm{Bu}_{4} \mathrm{NBr}(23.3 \mathrm{mg}, 72.3 \mu \mathrm{mol}, 1.25$ equiv.), DMF ( $2 \mathrm{~mL})$ and a solution of copolymer $\mathbf{A}(94.4 \mathrm{mg}, \sim 58 \mu \mathrm{mol}$ of bromododecyl) in THF $(30 \mathrm{~mL})$ were mixed in a pressure tube. The sealed tube was heated $96 \mathrm{~h}$ at $95^{\circ} \mathrm{C}$. THF was evaporated under vacuum and the crude was precipitated in $\mathrm{MeOH}(10 \mathrm{x}$ its volume). The precipitate was centrifuged $(9500 \mathrm{rpm})$ and dried for $24 \mathrm{~h}$ to afford polymer B (211 $\mathrm{mg}, 89 \%$ yield). ${ }^{1} \mathrm{H} \mathrm{NMR}\left(400 \mathrm{MHz} \mathrm{CDCl}_{3}\right): \delta(\mathrm{ppm}) 7.72(\mathrm{~d}, 0.28 \mathrm{H}, J=7.2 \mathrm{~Hz}$, imine phenyl), 7.47-7.33 (m, $0.42 \mathrm{H}$, imine phenyl), 7.25 (m, overlap with $\mathrm{CHCl}_{3}$,imine phenyl), $7.11(\mathrm{~m}, 0.28 \mathrm{H}$, imine phenyl), $6.98(\mathrm{~s}, 1 \mathrm{H}$, thiophene $\mathrm{C} 4-\mathrm{H}), 6.66(\mathrm{~m}, 0.56 \mathrm{H}, J=8.4 \mathrm{~Hz}$, aminophenol $\mathrm{H})$, $3.83\left(\mathrm{t}, 0.28 \mathrm{H}, \mathrm{J}=6.3 \mathrm{~Hz}, \mathrm{CH}_{2} \mathrm{O}\right), 2.81\left(\mathrm{~m}, 2 \mathrm{H}\right.$, dodecyl C1- $\left.\mathrm{H}_{2}\right), 1.51-1.87(\mathrm{~m}, 2 \mathrm{H}$, dodecyl $\left.\mathrm{C} 2-\mathrm{H}_{2}\right), 1.10-1.51\left(\mathrm{~m}, 18 \mathrm{H}\right.$, dodecyl $\mathrm{C} 3$ to $\left.\mathrm{C} 11-\mathrm{H}_{2}\right), 0.78-0.95\left(\mathrm{~m}, 3 \mathrm{H}, \mathrm{CH}_{3}\right) .{ }^{13} \mathrm{C} \mathrm{NMR}$ $\left(100 \mathrm{MHz}_{\mathrm{CDCl}}\right) \delta(\mathrm{ppm}): 167.8(\mathrm{C}=\mathrm{N}), 155.5(\operatorname{aryl} \mathrm{C}-\mathrm{O}), 144.3(\operatorname{aryl} \mathrm{C}-\mathrm{N}), 140.2\left(\mathrm{Ph}_{2} \mathrm{CN}\right.$ phenyl C1), 140.0 (thiophene $\mathrm{C} 3), 136.8$ ( $\mathrm{Ph}_{2} \mathrm{CN}$ phenyl $\left.\mathrm{C} 4\right), 136.8,133.7$ (thiophene $\mathrm{C} 5$ HTHT). 130.6 (thiophene C2), 129.7, 129.3, 128.8 (thiophene C4), 128.6, 128.7, 133.7 (C2 thiophene), 128.3, 128.2, 125.7, 122.7, 114.5, $68.2\left(\mathrm{CH}_{2} \mathrm{O}\right), 32.1\left(\mathrm{CH}_{2} \mathrm{CH}_{2} \mathrm{CH}_{3}\right) .30 .7$ (dodecyl C2), 29.89, 29.04, 29.75, 29.68, $29.6129 .55,26.2\left(\mathrm{CH}_{2} \mathrm{CH}_{2} \mathrm{CH}_{2}-\mathrm{O}\right), 22.8\left(\mathrm{CH}_{2} \mathrm{CH}_{3}\right)$, $14.3\left(\mathrm{CH}_{3}\right)$. FTIR (ATR diamond) $v\left(\mathrm{~cm}^{-1}\right)$ : 3054 (aromatic $\left.v \mathrm{CH}\right), 2953\left(v_{\text {as }} \mathrm{CH}_{3}\right), 2917$ $\left(v_{\text {as }} \mathrm{CH}_{2}\right), 2848\left(v_{\mathrm{s}} \mathrm{CH}_{2}\right), 1607$ (imine $\left.v \mathrm{CN}\right), 1567,1501,1446,1376\left(\delta \mathrm{CH}_{3}\right), 1315(\operatorname{aryl} \mathrm{C}-\mathrm{N}$ stretching), 1238 ( $\vee \mathrm{C}-\mathrm{O}$ ether), 1167 ( $\vee \mathrm{C}-\mathrm{O}$ ether), 1028, 958, 828, 819 (aromatic oop $\delta \mathrm{CH}$ ), 783, $720\left(\mathrm{rCH}_{2}\right), 693$.

Poly(3-dodecylthiophene-co-3-(12-(4-aminophenoxy)dodecyl)thiophene) (PDT-coADT): copolymer B (50.8 mg, $28 \mu \mathrm{mol}$ of imine) and hydroxylamine (50 wt.\% in water, $71 \mathrm{mg}, 1.07 \mathrm{mmol}, 38$ equiv.) were dissolved in THF (2 mL) and the mixture was stirred for $20 \mathrm{~h}$ at $50{ }^{\circ} \mathrm{C}$. The polymer was precipitated in methanol, centrifuged (9500 rpm, $2 \mathrm{~h}$ ) and dried for $24 \mathrm{~h}$. A shiny violet solid was obtained $\left(36.6 \mathrm{mg}, 72 \%\right.$ yield). ${ }^{1} \mathrm{H} \mathrm{NMR}$ $\left(400 \mathrm{MHz}, \mathrm{CDCl}_{3}\right) \delta(\mathrm{ppm}) 6.98(\mathrm{~s}, 1 \mathrm{H}$, thiophene $\mathrm{CH}, \mathrm{HTHT}), 6.72(\mathrm{~d}, 0.28 \mathrm{H}, J=8.7 \mathrm{~Hz}$, phenyl C2-H and C6-H), $6.62(\mathrm{~d}, 0.28 \mathrm{H}, J=8.7 \mathrm{~Hz}$, phenyl C3-H and C5-H), 5.02 (s, $\left.\mathrm{NH}_{2}\right), 3.85\left(\mathrm{t}, 0.28 \mathrm{H}, \mathrm{J}=6.4 \mathrm{~Hz}, \mathrm{CH}_{2} \mathrm{O}\right), 2.81\left(\mathrm{~m}, 2 \mathrm{H}, \mathrm{CH}_{2}\right.$-thiophene HTHT), $1.71(\mathrm{~m}, 2 \mathrm{H}$, $\mathrm{CH}_{2} \mathrm{CH}_{2}$-thiophene), $1.48-1.18\left(\mathrm{~m}, 18 \mathrm{H}, \mathrm{CH}_{2}\right), 0.88\left(\mathrm{t}, \mathrm{J}=6.5 \mathrm{~Hz}, 3 \mathrm{H}, \mathrm{CH}_{3}\right) .{ }^{13} \mathrm{C} \mathrm{NMR}$ $\left(400 \mathrm{MHz}, \mathrm{CDCl}_{3}\right) \delta$ (ppm): 140.0 (C3 thiophene HT-HT), 133.8 (C5 thiophene HTHT). 130.5 (C2 thiophene HT-HT), 128.8 (C4 thiophene HT-HT). 116.5 (aniline C2, C6), 115.7 (aniline C3, C5), $32.0\left(\mathrm{CH}_{3}\right), 68.8\left(\mathrm{CH}_{2} \mathrm{O}\right), 30.7\left(\mathrm{CH}_{2} \mathrm{CH}_{2}\right.$-thiophene dodecyl), 30.7, 29.9, 29.8, 29.7, 29.6, 29.5, 22.9, $29.4\left(\mathrm{CH}_{2} \mathrm{CH}_{2} \mathrm{CH}_{3}\right), 26.3\left(\mathrm{CH}_{2} \mathrm{CH}_{2} \mathrm{O}\right), 22.9\left(\mathrm{CH}_{2} \mathrm{CH}_{3}\right), 14.3\left(\mathrm{CH}_{3}\right)$. FTIR (ATR diamond) $v\left(\mathrm{~cm}^{-1}\right): 3359$ (large, NH stretching), 3055 (aromatic $\left.v \mathrm{CH}\right), 2949\left(\mathrm{vas}_{\mathrm{as}} \mathrm{CH}_{3}\right)$, $2918\left(v_{\mathrm{as}} \mathrm{CH}_{2}\right), 2849\left(v_{\mathrm{s}} \mathrm{CH}_{2}\right), 1625$ ( $\mathrm{NH}$ bend), 1562 ( $\mathrm{NH}$ bend), 1510 and 1465 (aromatic vCC), $1377\left(\delta \mathrm{CH}_{3}\right), 1236$ (vCO ether), 819 (oop aromatic $\left.\mathrm{CH}\right), 719\left(\mathrm{rCH}_{3}\right)$.

\subsection{Formation of the Polymer/SWNT Hybrids}

HiPCO SWNTs (mean diameter $1.0 \pm 0.2 \mathrm{~nm}$ ) were purchased from NanoIntegris (Boisbriand, QC, Canada). They were dried at $250{ }^{\circ} \mathrm{C}$ under vacuum prior to use.

SWNT mother suspension: HiPCO SWNTs were dried at $250{ }^{\circ} \mathrm{C}$ under vacuum. $1.6 \mathrm{mg}$ of the dry SWNTs were suspended in $5 \mathrm{~mL}$ of THF through tip sonication ( $5 \mathrm{~min}$, $80 \mathrm{~W}$, final concentration $0.32 \mathrm{mg} / \mathrm{mL}$ ).

Formation of the non-covalent hybrids: A mother solution of polymer was prepared by dissolving $3.1 \mathrm{mg}$ of PDTcoADT in $5 \mathrm{~mL}$ of THF (final concentration $0.62 \mathrm{mg} / \mathrm{mL}$ ). A typical suspension for study of non-covalent nanohybrids is prepared by diluting $100 \mu \mathrm{L}$ of this suspension in $5 \mathrm{~mL}$ of THF (final concentration $12.4 \mu \mathrm{g} / \mathrm{mL}$, dissolved mass $62 \mu \mathrm{g}$ ), which led to an absorbance of 0.19 ( $5 \mathrm{~mm}$ cell). Fractions of $100 \mu \mathrm{L}$ of the SWNT mother suspension (corresponding to $32 \mu \mathrm{g}$ per fraction) were added to the copolymer solution, which is then tip sonicated. This operation is repeated until aggregation of the carbon nanotubes happened immediately after sonication.

Formation of the covalent hybrids: covalent functionalization was performed on a non-covalent dispersion of SWNTs with PDTcoADT. $0.8 \mathrm{mg}$ of SWNTs were dispersed by sonication $(5 \mathrm{~min}, 80 \mathrm{~W})$ in $5 \mathrm{~mL}$ of a solution of PDTcoADT in THF $(0.3 \mathrm{mg} / \mathrm{mL}$, total amount $1.45 \mathrm{mg}$, corresponding to a SWNTs/polymer mass ratio of 0.55$)$. This suspension 
was degassed and put under nitrogen. $50 \mu \mathrm{L}$ of isoamyl nitrite were added, the suspension was degassed anew and heated to $60^{\circ} \mathrm{C}$ for $12 \mathrm{~h}$. The supernatant of the final system was recovered and then analyzed.

Samples for Raman analysis: $50 \mu \mathrm{L}$ of the recovered dispersions were deposited onto a glass plate by spin-coating. The obtained films were repeatedly washed with THF to eliminate the excess polymer.

\section{Results and Discussion}

\subsection{Design of the Compounds}

We aim at synthesizing a copolymer based on a poly(3-alkylthiophene) with side chains bearing aniline groups. As we have shown previously [15], when the alkyl chain is hexyl, this polymer is able to bind non-covalently with SWNTs, to form soluble polymer/SWNT hybrid complexes. The same hybrids heated in the presence of isoamyl nitrite react according to Tour's reaction: the aniline groups are transformed into a transitory diazonium that reacts with SWNTs to attach the phenyl of the aniline covalently to the SWNTs walls (Scheme 1). In the present work, we synthesize a new polymer with dodecyl side chains, i.e., twice longer than in hexyl analogues.

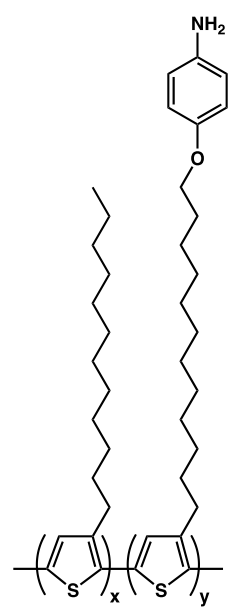

PDT COADT

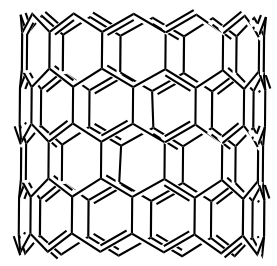

SWNT
Non-covalent SWNT/Polymer hybrids

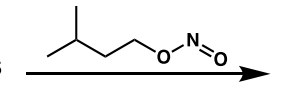

ovalent

SWNT/Polymer hybrids

Scheme 1. Structure of the targeted copolymers and their reaction with SWNTs.

\subsection{Syntheses of the Monomers and Polymers}

The copolymer was synthesized first by copolymerizing 2-bromo-3-dodecyle-5 -iodothiophene 1 and its end brominated analogue $\mathbf{2}$ (Scheme 2) by the Grignard metathesis (GRIM) method [19,20].
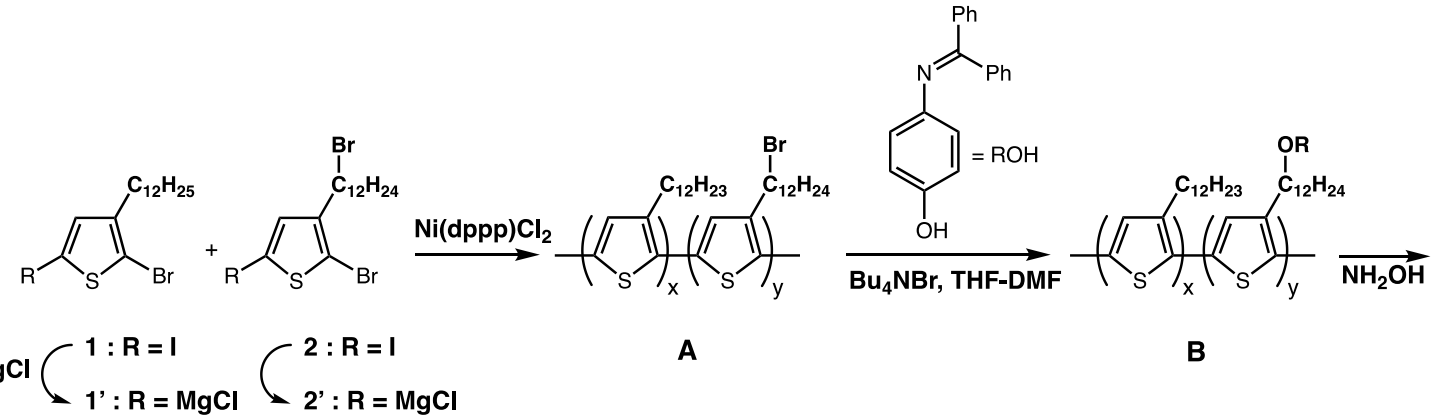

A

B

Scheme 2. Synthesis of the PDTcoADT copolymer. 
In a first step the monomers $\mathbf{1}$ and $\mathbf{2}$ were synthesized (Scheme 3 ) and then polymerized to afford polymer A bearing bromide at the end of the side chains (Scheme 2). As shown before [21], copolymerization with the bromo analogue is possible, and the end bromide does not interfer with the formation of the organomagnesium [21]. The choice of the iodine in position 5 adds a step to the synthesis of the monomer; but as shown by Catala et al. [22], it increases the regioselectivity of the metallation and subsequent polymerization. Moreover, both monomers have close reactivity, and we have shown that the composition of the polymer follows that of the feed mixture monomer [15], which suggests that the yielded polymer is a random copolymer. By the GRIM method, Yang et al. have also obtained random copolymers from thiophene based monomers with even larger structural differences than $\mathbf{1}$ and $\mathbf{2}$ [23].

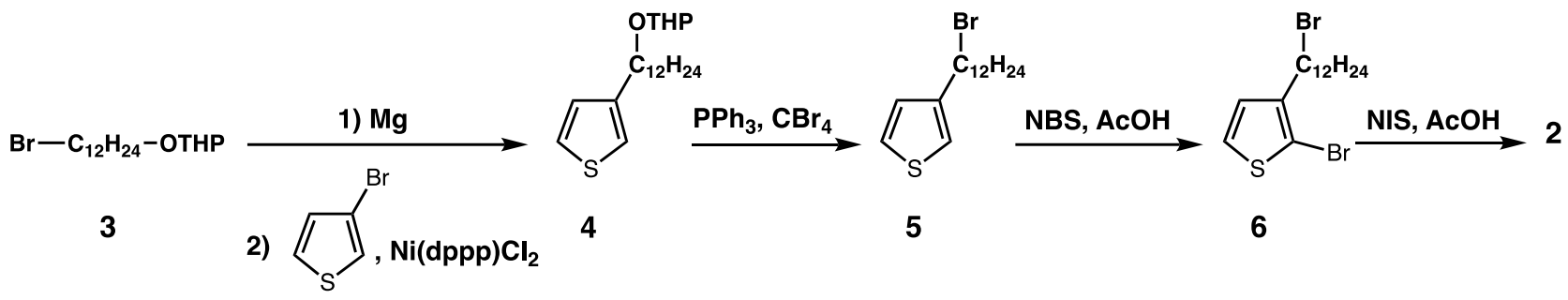

Scheme 3. Synthesis of the monomer 2.

The monomers were synthesized by coupling first the organomagnesium of $\mathrm{Br}^{-} \mathrm{C}_{12} \mathrm{H}_{24}$ OTHP with 3-bromothiophene, with $\mathrm{Ni}(\mathrm{dppp}) \mathrm{Cl}_{2}$ as the catalyst (Scheme 3). The reaction proceeds with a fair yield (about $67 \%$ ), but the compound 4 has a low polarity and has the same $\mathrm{R}_{\mathrm{f}}$ as two byproducts $\left(\mathrm{Br}-\mathrm{C}_{12} \mathrm{H}_{24}-\mathrm{OTHP}\right.$ and $\mathrm{C}_{12} \mathrm{H}_{25}$-OTHP) in cyclohexane. Therefore compound 4 was not separated from these products but transformed in the next steps. The THP ether was converted into bromide, and the resulting compound $\mathbf{5}$ was brominated selectively in position 2 and iodinated in position 5. Compounds 5, 6, and 2 are less polar than 4 , but can be purified by flash chromatography.

The monomer $\mathbf{1}$ and $\mathbf{2}$ were metallated with $i-\mathrm{PrMgCl}$. The formation of the resulting organomagnesium was followed by taking aliquots from the reaction and quenching them with $\mathrm{CD}_{3} \mathrm{OD}$. The species $\mathbf{1}^{\prime}$ and $\mathbf{2}^{\prime}$ are deuterated in position 5 and the resulting compound, has only one proton yielding a singlet at $6.78 \mathrm{ppm}$, the major peak in this area (Figure 1). The unreacted compound 2 can be identified by a singlet at $6.96 \mathrm{ppm}$. Another present species is characterized by two doublets: the first at $7.18 \mathrm{ppm}$, and the second which overlaps with the main peak. It corresponds to the organomagnesium that was hydrolyzed by protonated impurities in the mixture before quenching. The resulting compound has two protons in position 4 and 5 and is clearly distinct from the one coming from the deactivation of the active species by $\mathrm{CD}_{3} \mathrm{OD}$. It allows to measure exactly the ratio of active species and adapt the amount of catalyst to control the length of the polymer.

The polymerization is initiated by the addition of the catalyst, and the propagation is followed in situ by UV by measuring the absorbance at $445 \mathrm{~nm}$. The obtained polymer A has a $M_{n}$ of $41,000\left(\mathrm{DP}_{\mathrm{n}} \sim 155\right)$ as determined by MALS, and a polymolecularity index of 1.42 (Figure 2a). The polymer was tentatively purified by recycling SEC in chloroform. The mass distribution was slightly improved with a polymolecularity of 1.37 . The ratio of bromide in the polymer was measured by integrating of the triplet at $3.41 \mathrm{ppm}$ characteristic of $\mathrm{CH}_{2} \mathrm{Br}$, and the massif centered at $2.45 \mathrm{ppm}$ from the $\mathrm{CH}_{2}$ in alpha of the thiophene (Figure $2 \mathrm{~b}$ ). From the ratio of both, one measures a rate of bromine in the polymer of $16.5 \pm 2 \%$. This rate represents an average of 25 brominated side chains per polymer chain.

The functionalized side chains were etherified by an excess of 4-aminophenol, $\mathrm{N}$ protected as its diphenylimine, with a phase transfer catalyst (Scheme 2). The rate of substitution in the final polymer is quantitative as shown by the total disappearance of the $\mathrm{CH}_{2} \mathrm{Br}$ signals in NMR. The aniline was deprotected by transamination with hydroxylamine 
in THF to afford the final polymer. It must be stored at $0{ }^{\circ} \mathrm{C}$ under Ar since it tends to degrade and crosslink.

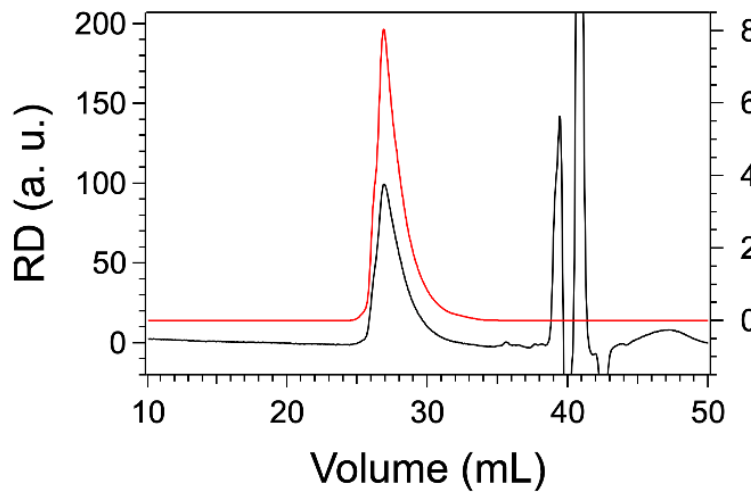

(a)

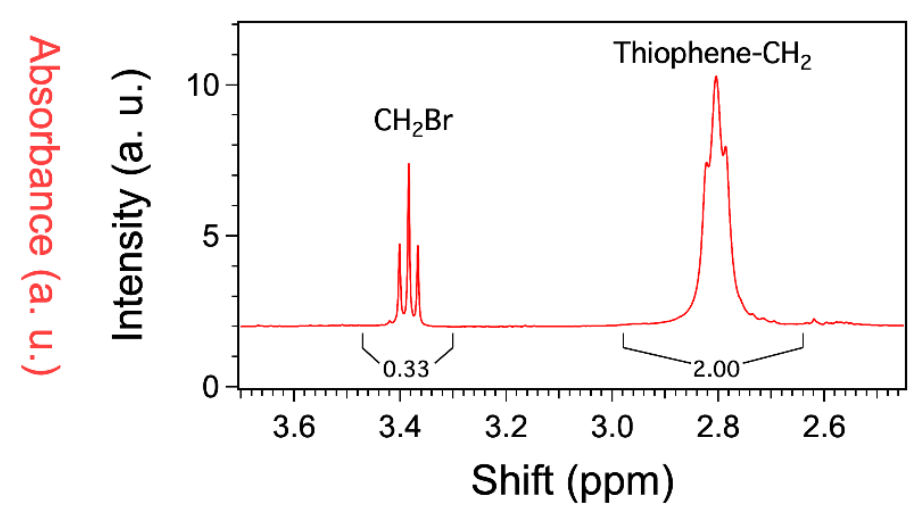

(b)

Figure 2. Characterization of copolymer A (41,000 g/mol) (a) SEC traces: RD and UV absorbance at 448 nm; (b) Enlarged NMR spectrum showing the proton in benzylic position and next to $\mathrm{Br}$, with the corresponding integrals.

\subsection{Formation and Study of the Non-Covalent Copolymer/SWNT Hybrids}

The non-covalent functionalization of SWNTs was studied by adding repeatedly the same amount of SWNTs $(32 \mu \mathrm{g})$ to a solution of PDTcoADT (62 $\mu \mathrm{g}$ in $5 \mathrm{~mL}$, conc. $12.4 \mu \mathrm{g} / \mathrm{mL}$ ). During the first additions, the resulting suspensions are stable for a few hours; after a given number of additions, corresponding to a threshold SWNT/PDTcoADT mass ratio, the SWNTs are no longer suspended and precipitate immediately.

After each addition of SWNTs to PDTcoADT, the suspensions were studied by UV-VisNIR (Figure 3). The starting polymer solution, without SWNTs shows only one broad peak at $450 \mathrm{~nm}$. This peak represents the free copolymer in solution. When the amount of SWNTs increases, this peak decreases. At the same time, we observe an increase of the background absorption corresponding to the tail of the SWNTs $\pi$-plasmon absorption (around $180 \mathrm{~nm}$ ), the appearance of two sets of peaks between 700 and $1500 \mathrm{~nm}$, corresponding to SWNTs optical transitions, and the appearance of peaks between 500 and $650 \mathrm{~nm}$. These latter peaks are characteristic of aggregates of regioregular P3HT formed by $\pi$-stacked planar and extended polymer chains [24]. The absence of these bands in the starting solution shows that PDTcoADT is fully soluble in THF at this concentration. The appearance of these bands in the presence of SWNTs strongly suggests $\pi-\pi$ interactions between the copolymer chains and the SWNTs in the hybrids. In the spectra measured during these experiments, the characteristic features of both polymer aggregates and SWNTs do not change significantly, indicating a similar molecular array at the interface of the hybrids.

For the maximal SWNT/PDTcoADT mass ratio, the contribution of the peak of the free polymer at $450 \mathrm{~nm}$ is less than $10 \%$ of the intensity of the signal (Figure 4). It indicates that all the polymer chains are adsorbed on SWNTs. As found previously [15], for the analogue copolymer PHTcoAHT, with hexyl side chains, with the same aniline ratio and a $M_{n}$ of 36,000 ( $\mathrm{DP}_{\mathrm{n}}$ of 200), the contribution of the free polymer at $450 \mathrm{~nm}$ is of about $30 \%$ of the intensity of the signal for a critical mass ratio of 1.26. In summary, the first effect of lengthening the side chain is a better stacking of the polymer chains on the SWNTs.

The threshold ratio above which spontaneous flocculation occurs is $2.9 \pm 0.6 \mathrm{mg}$ of SWNTs per mg of PDTcoADT. This ratio corresponds to $780 \mathrm{mg}$ of SWNTs per mmol of PDTcoADT. As shown previously [15], for the hexyl analogue, the critical ratio is of $230 \mathrm{mg}$ of SWNTs per mmol of PHTcoAHT. It shows that the dodecyl analogue solubilizes 3.3 times more SWNTs than the hexyl analogue. This difference is attributed to the better solubility in THF of the dodecyl copolymer due to more flexibility of the polymer backbone and its side chains in solution, which facilitates the optimization of their configuration to wrap around the SWNTs [18]. 


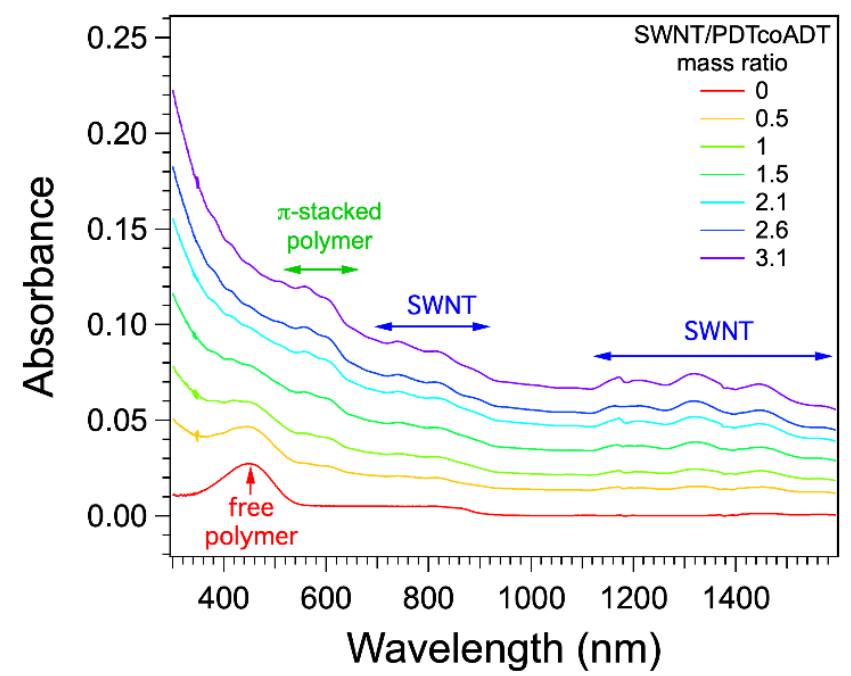

Figure 3. Evolution UV-Vis-NIR spectra of a solution of PDTcoADT $(0.62 \mu \mathrm{g}$, conc. $0.124 \mu \mathrm{g} / \mathrm{mL})$ after repeated additions of the same amount of SWNTs $(0.32 \mu \mathrm{g})$.

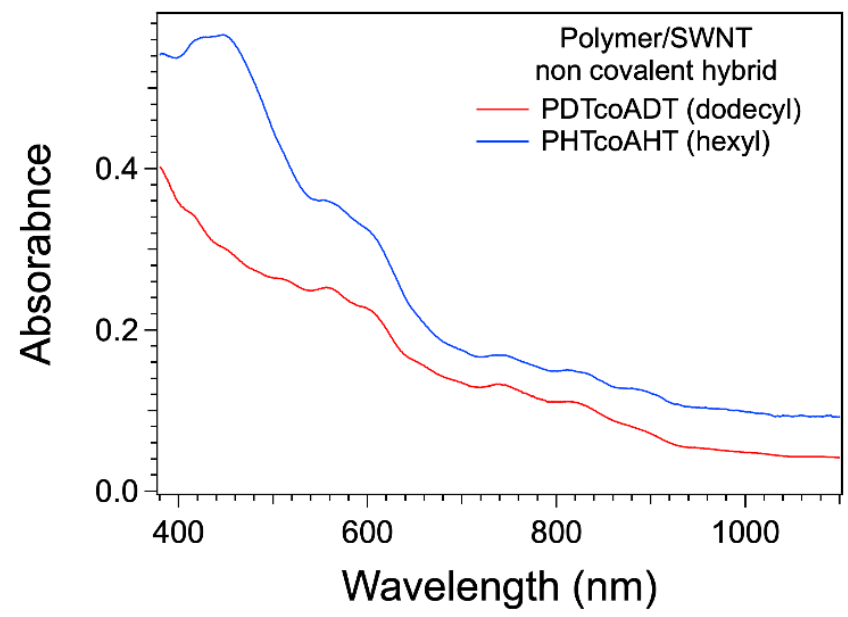

Figure 4. Spectra of the non-covalent nanohybrids before the onset of flocculation for PDTcoADT (red, SWNTs/polymer mass ratio = 3.1) and comparison with the spectrum of PHTcoAHT (blue, SWNTs / polymer mass ratio $=1.26$, from reference [15]).

In parallel to their absorbance, the photoluminescence of the non-covalent PDTcoADT hybrids was measured during their formation (Figure 5). When the mere copolymer, without SWNT, is excited at $450 \mathrm{~nm}$, it gives rise to a fluorescence emission which peaks at $570 \mathrm{~nm}$. Upon addition of incremental amounts of SWNTs, we observe a reduction of emission intensity concomitant to the reduction of the free polymer contribution in the absorption spectrum, but no change of the shape of the photoluminescence spectra. Moreover, one observes no characteristic emission of polymer aggregates at 630 and $690 \mathrm{~nm}$ [25], even upon excitation at $560 \mathrm{~nm}$, corresponding to the maximum of their optical absorption. These results, similar to those obtained with PHTcoAHT [15], confirm that the aggregates form on the SWNTs surface and have their fluorescence quenched by their interaction with these species. 


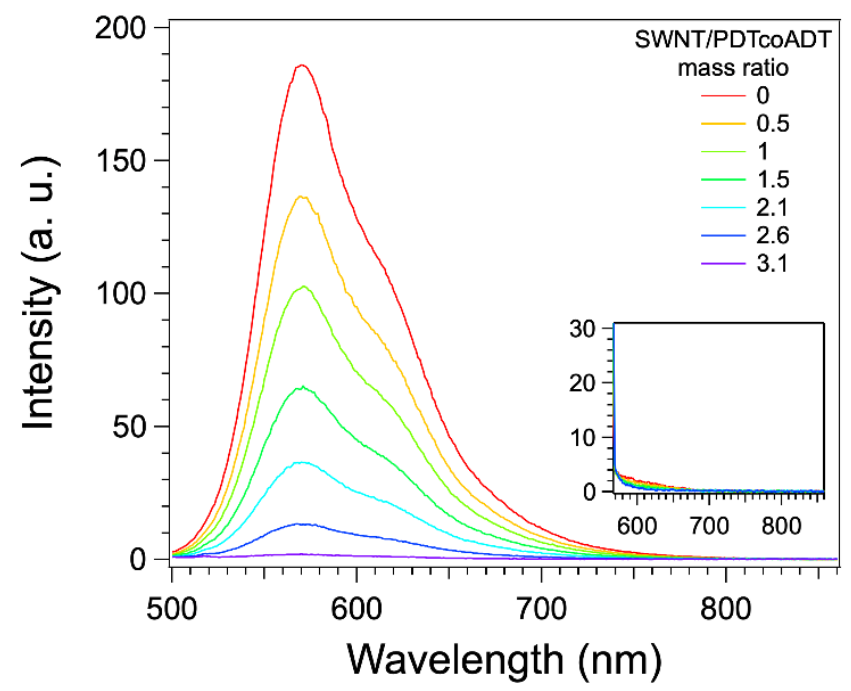

Figure 5. Photoluminescence spectra of the suspensions of non-covalent hybrids for different SWNTs/PDTcoADT mass ratios; excitation at $450 \mathrm{~nm}$; inset: excitation at $560 \mathrm{~nm}$, at the same scale, showing no PL.

\subsection{Formation of the Covalent Hybrids}

Covalent functionalization is performed starting from the non-covalent nanohybrids. In order to conduct the reaction on stable suspensions, the SWNTs/copolymer mass ratio is set at 0.55 , well below the flocculation threshold of 2.9 found in the previous section. We use a higher concentration of both species for increasing the final amount of covalent nanohybrids.

After the reaction, the suspensions are stable for a few days. Therefore, lengthening the side chains lowers the stability of the covalent hybrids: the hybrids obtained with the hexyl analogue PHTcoAHT were stable for a few weeks. This lower stability was unexpected. Moreover, with the dodecyl polymer most of the material precipitates under centrifugation, which prevents separating reacted from unreacted SWNTs. For this reason, the spectroscopic characterizations have been performed on the raw suspensions (without centrifugation).

After the reaction, the UV-Vis spectrum of the sample still exhibits the absorption signals of both copolymer and SWNTs but not the characteristic features of PDTcoADT aggregates between 500 and $650 \mathrm{~nm}$. Thus, the reaction induces a change in the organization of the polymer in the covalent hybrids compared to the non-covalent ones (Figure 6).

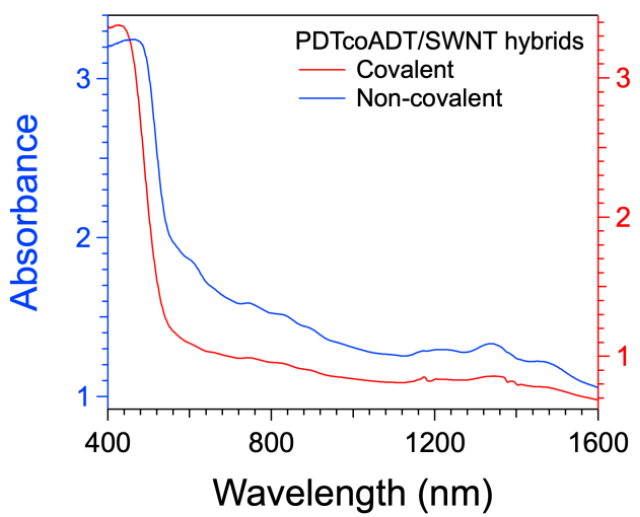

(a)

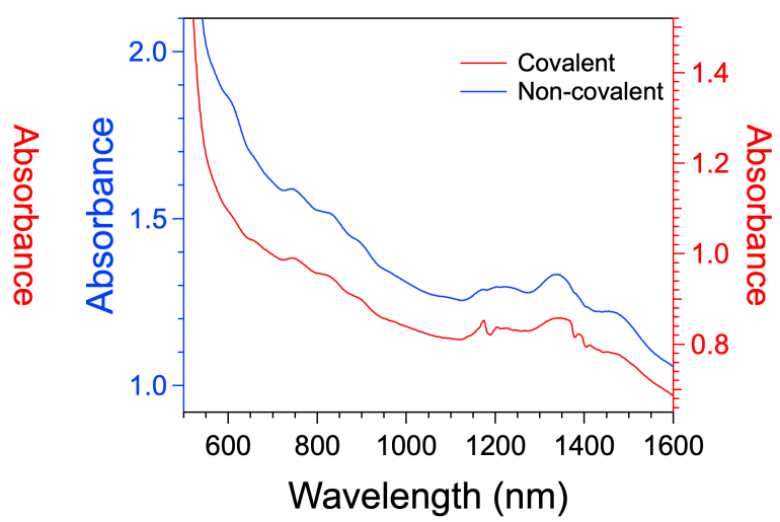

(b)

Figure 6. (a) UV-Vis spectra of the non-covalent (blue line, left scale) and covalent (red line, right scale) PDTcoADT/SWNT nanohybrids. Since higher concentrations were used, the absorption by the free polymer and the isoamyl nitrite saturates the signal at low wavelengths. (b) Same spectra focused on the polymer aggregates and SWNTs absorption. 
The results of Raman spectroscopy allow the study of the conformation of the polymer onto the surface of SWNTs; they are shown in Figure 7. The modes of SWNTs are the D band around $1320 \mathrm{~cm}^{-1}$ and the $G$ modes in the $1500-1600 \mathrm{~cm}^{-1}$ range. For the three samples they have close frequencies and the $D / G$ intensity ratios are the same. This is in agreement with the expected low amount of grafting bonds $\left(10^{-3}\right.$ per $\mathrm{C}$ atom) and a large distance between defects, of the order of 2-3 nm $[7,26]$. On the contrary, the lineshape of the modes of the PDTcoADT, located in the $1350-1500 \mathrm{~cm}^{-1}$ range, and assigned to the $\mathrm{C}-\mathrm{C}$ and $\mathrm{C}=\mathrm{C}$ stretching modes, are different in the non-covalent and covalent samples (Figure $8 \mathrm{~b}$ ). This indicates clearly that the organization of the copolymer is not the same in both hybrids [27].

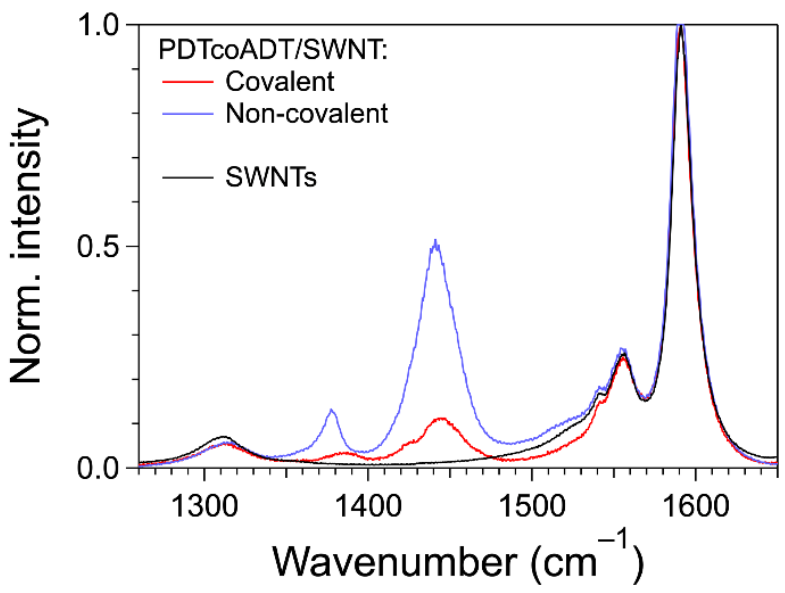

(a)

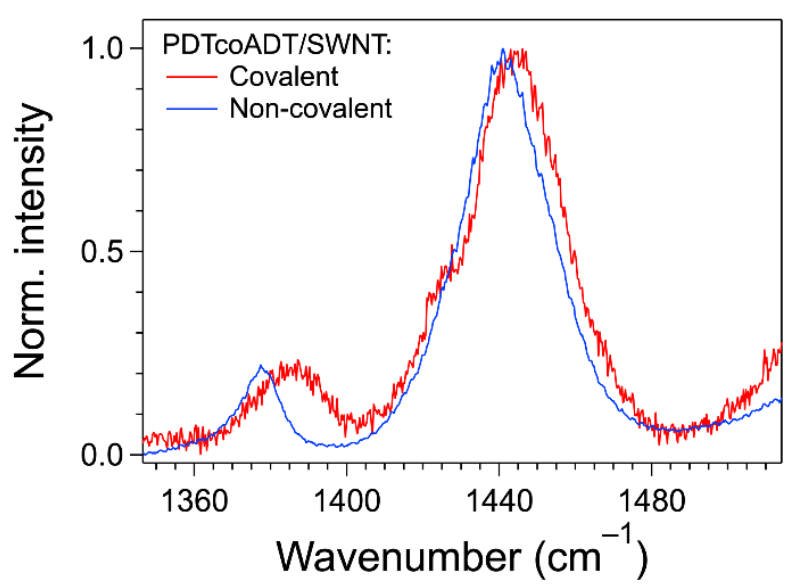

(b)

Figure 7. (a) High frequency Raman spectra (excitation at $633 \mathrm{~nm}$ ) of pristine SWNTs (black) and of covalent (red) and noncovalent (blue) PDTcoADT/SWNT nanohybrids. The spectra are normalized by the intensity of the $\mathrm{G}$ mode at $1590 \mathrm{~cm}^{-1}$. (b) same spectra focused on the $\mathrm{C}-\mathrm{C}$ and $\mathrm{C}=\mathrm{C}$ vibration modes, normalized by their intensity at $1445 \mathrm{~cm}^{-1}$.

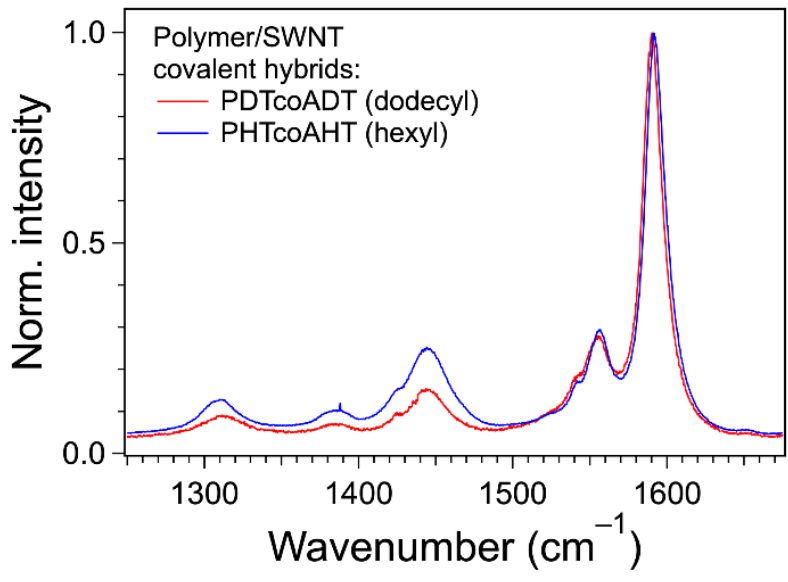

(a)

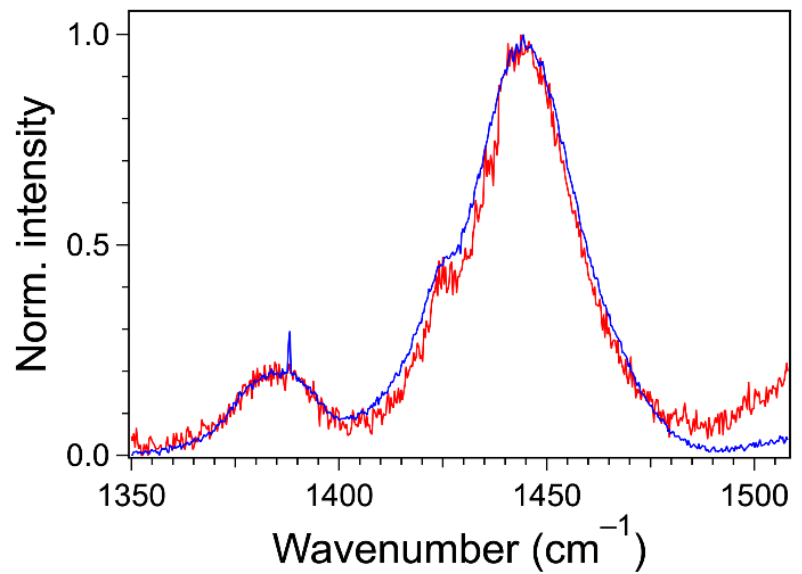

(b)

Figure 8. (a) High frequency Raman spectra (excitation at $633 \mathrm{~nm}$ ) of covalent PDTcoADT/SWNTs (red) and covalent PHTcoAHT/SWNTs (blue) nanohybrids. The spectra were normalized by the intensity of the G mode at $1590 \mathrm{~cm}^{-1}$. (b) same spectra focused on the $\mathrm{C}-\mathrm{C}$ and $\mathrm{C}=\mathrm{C}$ vibration modes, normalized by their intensity at $1445 \mathrm{~cm}^{-1}$.

The intensity of the PDTcoADT signal is higher for the non-covalent nanohybrid than for the covalent one. This is in agreement with the formation of polymer aggregates in the non-covalent nanohybrids and their absence in the covalent nanohybrids, as observed by UV-Vis. The shift and broadening of the mode at $1380 \mathrm{~cm}^{-1}$, the small upshift of the mode at $1450 \mathrm{~cm}^{-1}$, and the appearance of a shoulder on its left side have been interpreted 
by a loss of the molecular order of PHTcoAHT chains in the covalent nanohybrids [15]. This result is due to the absence of $\pi$-stacking of the thiophene units onto the SWNTs because, after covalent grafting, the appended aniline acts as a spacer between SWNTs and the PHTcoAHT backbone. Since the spectra of the covalent PDTcoADT/SWNTs are close to those of hexyl analogues, we conclude that the polymer backbones adopt a similar conformation in both systems (Figure 8).

Therefore, the lower solubility of covalent PDTcoADT/SWNTs compared to that of PHTcoAHT/SWNTs cannot be attributed to a difference in the polymer conformation. It could be attributed to a better exfoliation of SWNTs by PHTcoAHT than by PDTcoADT, PDTcoADT may be able to solubilize larger but non-exfoliated bundles by non-covalent functionalization. This would agree with PDTcoADT solubilizing 3 times more SWNTs than the hexyl analogues. However, this contradicts the findings of Lee et al. [18]. Another explanation for the lower solubility of the covalent PDTcoADT/SWNTs is that longer alkyl chains could favor bridging reaction of neighbouring tubes during the covalent derivatization. This reactivity may be underpinned also by a higher solubility of the polymers in the solvent, and weaker interaction between the polymer and the tubes in the non-covalent hybrids.

\section{Conclusions}

The copolymer PDTcoADT was synthesized at the scale of hundreds of mg by copolymerization of 3-dodecylthiophene and its aniline appended analogue. It was obtained with high regioregularity. This polymer is able to form both non-covalent and covalent hybrids. In the non-covalent nanohybrids, the polymer forms $\pi$-stacked aggregates at the surface of the nanotubes, while it is no longer $\pi$-stacked in the covalent hybrids. This behavior is the same as for the analogue polymer with shorter hexyl side chains, PHTcoAHT, previously reported. The new results are that lengthening the side chains resulted in the dispersion of a higher amount of SWNTs. Lengthening the side-chain also increases the proportion of polymer chains $\pi$-stacked at the surface of the tube. Very surprisingly the PDTcoADT/SWNTs covalent nanohybrids were insoluble in THF, contrary to PHTcoAHT/SWNTs. From our spectroscopic studies, this result cannot be explained by the conformation of the polymer at the surface of nanotubes, and further studies will be conducted to address this difference of behavior.

Author Contributions: Conceptualization, P.P. and P.J.M.; methodology, P.P. and P.J.M.; investigation, F.W.K. and J.P.L.; writing—original draft preparation, F.W.K. and P.J.M.; writing—review and editing, F.W.K., J.-P.L., M.P., P.P., and P.J.M.; supervision, M.P., P.P., and P.J.M.; funding acquisition, M.P. and P.P. All authors have read and agreed to the published version of the manuscript.

Funding: This research was funded by the French Agence Nationale de la Recherche, Grant No. ANR-13-BS10-0014, project GAMBIT.

Institutional Review Board Statement: Not applicable.

Informed Consent Statement: Not applicable.

Data Availability Statement: The data presented in this study are available on request from the corresponding author. The data are not publicly available due to lack of dedicated server.

Acknowledgments: $\mathrm{C}$. Foussat and the facility of polymer characterization are acknowledged for the SEC measurements and for the use of the UV and FTIR spectrometer. J. M. Catala is acknowledged for helpful discussion.

Conflicts of Interest: The authors declare no conflict of interest.

\section{References}

1. Campidelli, S. Click Chemistry for Carbon Nanotubes Functionalization. Curr. Org. Chem. 2011, 15, 1151-1159. [CrossRef]

2. Li, H.; Cheng, F.; Duft, A.M.; Adronov, A. Functionalization of Single-Walled Carbon Nanotubes with Well-Defined Polystyrene by "Click" Coupling. J. Am. Chem. Soc. 2005, 127, 14518-14524. [CrossRef] [PubMed] 
3. Ma, P.-C.; Siddiqui, N.A.; Marom, G.; Kim, J.-K. Dispersion and functionalization of carbon nanotubes for polymer-based nanocomposites: A review. Compos. Part A Appl. Sci. Manuf. 2010, 41, 1345-1367. [CrossRef]

4. Nurazzi, N.M.; Sabaruddin, F.A.; Harussani, M.M.; Kamarudin, S.H.; Rayung, M.; Asyraf, M.R.M.; Aisyah, H.A.; Norrrahim, M.N.F.; Ilyas, R.A.; Abdullah, N.; et al. Mechanical Performance and Applications of CNTs Reinforced Polymer Composites-A Review. Nanomaterials 2021, 11, 2186. [CrossRef]

5. Nurazzi, N.M.; Asyraf, M.R.M.; Khalina, A.; Abdullah, N.; Sabaruddin, F.A.; Kamarudin, S.H.; Ahmad, S.; Mahat, A.M.; Lee, C.L.; Aisyah, H.A.; et al. Fabrication, Functionalization, and Application of Carbon Nanotube-Reinforced Polymer Composite: An Overview. Polymers 2021, 13, 1047. [CrossRef] [PubMed]

6. Chen, Y.; Marty, L.; Bendiab, N. New Light on Molecule-Nanotube Hybrids. Adv. Mater. 2019, 31, 1902917. [CrossRef] [PubMed]

7. Piao, Y.; Meany, B.; Powell, L.R.; Valley, N.; Kwon, H.; Schatz, G.C.; Wang, Y. Brightening of carbon nanotube photoluminescence through the incorporation of sp3 defects. Nat. Chem. 2013, 5, 840-845. [CrossRef] [PubMed]

8. Bahr, J.L.; Tour, J.M. Highly Functionalized Carbon Nanotubes Using in Situ Generated Diazonium Compounds. Chem. Mater. 2001, 13, 3823-3824. [CrossRef]

9. Strano, M.S.; Dyke, C.A.; Usrey, M.L.; Barone, P.W.; Allen, M.J.; Shan, H.; Kittrell, C.; Hauge, R.H.; Tour, J.M.; Smalley, R.E. Electronic Structure Control of Single-Walled Carbon Nanotube Functionalization. Science 2003, 301, 1519-1522. [CrossRef]

10. Dyke, C.A.; Tour, J.M. Covalent functionalization of single-walled carbon nanotubes for materials applications. J. Phys. Chem. A 2004, 108, 11151-11159. [CrossRef]

11. Berger, F.J.; Lüttgens, J.; Nowack, T.; Kutsch, T.; Lindenthal, S.; Kistner, L.; Müller, C.C.; Bongartz, L.M.; Lumsargis, V.A.; Zakharko, Y.; et al. Brightening of Long, Polymer-Wrapped Carbon Nanotubes by sp 3 Functionalization in Organic Solvents. ACS Nano 2019, 13, 9259-9269. [CrossRef] [PubMed]

12. Liu, J.; Ye, Y.; Xue, Y.; Xie, X.; Mai, Y.-W. Recent advances in covalent functionalization of carbon nanomaterials with polymers: Strategies and perspectives. J. Polym. Sci. Part A Polym. Chem. 2017, 55, 622-631. [CrossRef]

13. Abousalman-Rezvani, Z.; Eskandari, P.; Roghani-Mamaqani, H.; Salami-Kalajahi, M. Functionalization of carbon nanotubes by combination of controlled radical polymerization and "grafting to" method. Adv. Colloid Interface Sci. 2020, $278,102126$. [CrossRef] [PubMed]

14. Díez-Pascual, A.M. Chemical Functionalization of Carbon Nanotubes with Polymers: A Brief Overview. Macromol 2021, 1, 64-83. [CrossRef]

15. Wasem Klein, F.; Lamps, J.-P.; Raoui, M.; Paillet, M.; Sauvajol, J.-L.; Mésini, P.J.; Petit, P. Design and synthesis of aniline-appended P3HT for single step covalent functionalisation of carbon nanotubes. Polym. Chem. 2020, 11, 6319-6327. [CrossRef]

16. Gomulya, W.; Costanzo, G.D.; De Carvalho, E.J.F.; Bisri, S.Z.; Derenskyi, V.; Fritsch, M.; Fröhlich, N.; Allard, S.; Gordiichuk, P.; Herrmann, A.; et al. Semiconducting single-walled carbon nanotubes on demand by polymer wrapping. Adv. Mater. 2013, 25, 2948-2956. [CrossRef] [PubMed]

17. Fong, D.; Adronov, A. Recent developments in the selective dispersion of single-walled carbon nanotubes using conjugated polymers. Chem. Sci. 2017, 8, 7292-7305. [CrossRef]

18. Lee, H.W.; Yoon, Y.; Park, S.; Oh, J.H.; Hong, S.; Liyanage, L.S.; Wang, H.; Morishita, S.; Patil, N.; Park, Y.J.; et al. Selective dispersion of high purity semiconducting single-walled carbon nanotubes with regioregular poly(3-alkylthiophene)s. Nat. Commun. 2011, 2, 541-548. [CrossRef]

19. Miyakoshi, R.; Yokoyama, A.; Yokozawa, T. Catalyst-Transfer Polycondensation. Mechanism of Ni-Catalyzed Chain-Growth Polymerization Leading to Well-Defined Poly(3-hexylthiophene). J. Am. Chem. Soc. 2005, 127, 17542-17547. [CrossRef]

20. Iovu, M.C.; Sheina, E.E.; Gil, R.R.; McCullough, R.D. Experimental Evidence for the Quasi-“Living” Nature of the Grignard Metathesis Method for the Synthesis of Regioregular Poly(3-alkylthiophenes). Macromolecules 2005, 38, 8649-8656. [CrossRef]

21. Tahar-Djebbar, I.; Nekelson, F.; Heinrich, B.; Donnio, B.; Guillon, D.; Kreher, D.; Mathevet, F.; Attias, A.-J. Lamello-Columnar Mesophase Formation in a Side-Chain Liquid Crystal $\pi$-Conjugated Polymer Architecture. Chem. Mater. 2011, 23, $4653-4656$. [CrossRef]

22. Vallat, P.; Lamps, J.P.; Schosseler, F.; Rawiso, M.; Catala, J.M. Quasi-Controlled Polymerization through a Nickel Catalyst Process of a Functionalized Thiophene Monomer: Kinetic Studies and Application to the Synthesis of Regioregular Poly(thiophene-3-acetic acid). Macromolecules 2007, 40, 2600-2602. [CrossRef]

23. Yang, Y.-L.; Lee, Y.-H.; Lee, Y.-P.; Chiang, C.-J.; Shen, C.; Wu, C.-C.; Ohta, Y.; Yokozawa, T.; Dai, C.-A. Synthesis and characterization of poly(3-hexylthiophene)-poly(3-hexyloxythiophene) random copolymers with tunable band gap via Grignard metathesis polymerization. Polym. Int. 2014, 63, 2068-2075. [CrossRef]

24. Spano, F.C.; Silva, C. H- and J-Aggregate Behavior in Polymeric Semiconductors. Annu. Rev. Phys. Chem. 2014, 65, 477-500. [CrossRef] [PubMed]

25. Rumbles, G.; Samuel, I.D.W.; Magnani, L.; Murray, K.A.; DeMello, A.J.; Crystall, B.; Moratti, S.C.; Stone, B.M.; Holmes, A.B.; Friend, R.H. Chromism and luminescence in regioregular poly(3-dodecylthiophene). Synth. Met. 1996, 76, 47-51. [CrossRef]

26. Giulianini, M.; Waclawik, E.R.; Bell, J.M.; Crescenzi, M.D.; Castrucci, P.; Scarselli, M.; Diociauti, M.; Casciardi, S.; Motta, N. Evidence of Multiwall Carbon Nanotube Deformation Caused by Poly(3-hexylthiophene) Adhesion. J. Phys. Chem. C 2011, 115, 6324-6330. [CrossRef]

27. Wood, S.; Hollis, J.R.; Kim, J.-S. Raman spectroscopy as an advanced structural nanoprobe for conjugated molecular semiconductors. J. Phys. D Appl. Phys. 2017, 50, 073001. [CrossRef] 